\title{
SARCOPENIA OF AGING
}

\author{
Kostas Stiklioraitis $^{1}$, Simas Stiklioraitis ${ }^{2}$, Liveta Sereikaité2, \\ Monika Jasinskaitė ${ }^{2}$, Žilvinas Krivickas ${ }^{2}$, Ali Aldujeli ${ }^{3}$ \\ ${ }^{1}$ University College London, Division of Biosciences Gower Street, London, \\ ${ }^{2}$ Lithuanian University of Health Sciences, Faculty of Medicine, Kaunas, Lithuania, \\ ${ }^{3}$ Lithuanian University of Health Sciences Kaunas Clinics, Department of Cardiology, Lithuania
}

Keywords: sarcopenia, aging, muscle loss.

\begin{abstract}
Summary
Background. Sarcopenia is an age-related condition, defined by the muscle decline, impaired physical function, and deterioration in muscle tissue quality. The main cause for the interest of Sarcopenia is the apparent association of this disease with patient morbidity, mortality, prolonged hospitalization, and deterioration in the quality of life. The purpose of this review is to present a brief account of some age-related biological changes that may contribute to Sarcopenia.

Materials and methods. We reviewed the literature based on data from Medline (PubMed), Google Scholar, Science Direct, and CAIRN. The research was done on articles in English or French, published before the 31st of December 2019. The research was based on the following Mesh headings (Medical Subject Headings): "sarcopenia" AND "aging" OR "muscle loss".

Conclusions. A multitude of etiological factors influences the aging-associated deterioration of muscle mass and function that constitute Sarcopenia, such as imbalanced protein synthesis and degradation, decreasing anabolic hormones, inflammation, and age-related morphological changes, which are described in the review. In the future, research might be conducted for identifying specific biomarkers, which may lead to an opportunity to assess and monitor the disease non-invasively, granting possibilities for a more efficient therapeutic approach.
\end{abstract}

\section{Introduction}

Sarcopenia is the aging-associated gradual loss of muscle mass, strength and function
(Fig.1), recognized as having an important role in adverse health-outcomes that are linked to advanced-age, including morbidity, mortality, frailty, and others (1). The etiology of Sarcopenia is multifactorial, with environmental causes, age-related decreases in anabolic hormones, active inflammatory-pathways, and morphological skeletal muscle changes, being a few of the contributing factors (2).

The aim of this review - to present a brief account of some age-related biological changes that may contribute to Sarcopenia.

\section{Materials and methods}

We reviewed the literature based on data from PubMed, Google Scholar, Science Direct, and CAIRN. The research was done on articles in English or French, published before the 31 st of December 2019. The research was based on the following Mesh headings (Medical Subject Headings): "sarcopenia" AND "aging" OR "muscle loss".

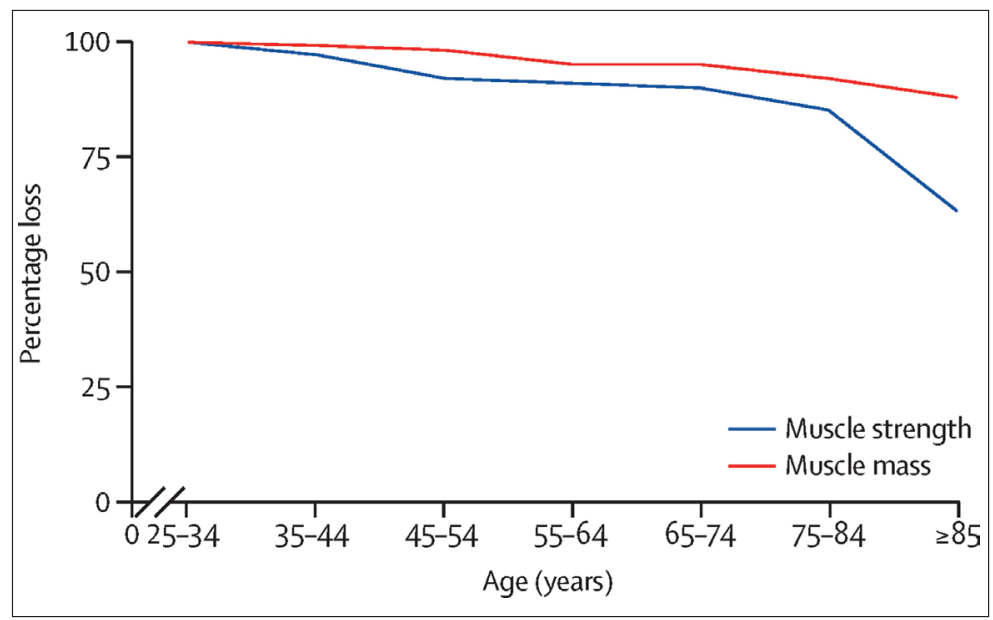

Figure 1. Muscle Mass and Strength Decline with Age. Figure taken from Cruz-Jentoft et al. (3) 


\section{Results}

This literature review revealed the key factors of age-related biological changes that may contribute to Sarcopenia. 19 studies were used for this non-systematic review. These studies were either uncontrolled $(\mathrm{N}=14)$ or reviews of the literature $(\mathrm{N}=5)$. The quality of the methodology limited the interpretation of the results and their extrapolation. Another limitation was study designs which included animal trials. Future studies are necessary to conclude the correlation between animal and human trials with similar study design.

\section{Epidemiology}

Recent large-scale population studies have established that the incidence of Sarcopenia increases with advanced age $(4,5,6)$. The average annual incidence rates were $1.6 \%$ for European men between the age of 40-79 (4), 3.1\% in Chinese populations $\geq 65$ years in age (5), and $3.6 \%$ among the very old ( $\geq 85$ years) in the United Kingdom (6). Cognitive impairments, low body mass indexes (BMI), and low socioeconomic positions were some of the common risk factors associated with increased incidence. Importantly, patients with Sarcopenia have a 3.59\% higher average mortality rate, and suffer from increased risks of falling, hospitalization, and overall functional decline (7). This has meant that the condition is now being linked to growing health-care costs (8).

\section{Pathophysiology}

Imbalanced Protein Synthesis and Degradation. A primary cause in the loss of skeletal muscle is the aging-associated imbalance of muscle protein synthesis and breakdown (9). Dietary intake of amino acids and proteins enhances muscle protein synthesis and reduces protein degradation; however, recent evidence has shown that the capability to respond to anabolic stimuli declines with age (9). One report (10) compared anabolic responses in 44 young and elderly men following ingestion of essential amino-acids, and found that young-people, on average, had a 1.5-fold higher rate of protein synthesis. This was associated with decreased expression and activation (by 30-50\%) of key anabolic signaling pathway components - namely, mTOR, p70 ${ }^{\mathrm{s} 6}$ kinase and eIF4BP-1 in the elderly. Further support is provided by a recent study (11) that compared the in vivo postprandial muscle-protein synthesis using stable-isotope infusion, and found that older men had a 3-fold smaller capacity to elevate protein-synthesis following food-ingestion.

Decreasing Anabolic Hormones. Furthermore, agingrelated reductions in anabolic-hormones, including testosterone and growth hormone $(\mathrm{GH})$, and decreased levels of insulin-like growth factor 1 (IGF-1), are linked to declining muscle cell synthetic capacity and function (12). A longi- tudinal study in 221 men (71-86 years in age) found that testosterone levels decrease by $7 \%$ during a 4-year timespan (13), whilst another report showed that GH production decreases by approximately $14 \%$ per decade (14). An animal study (15) demonstrated that the injection of recombinant human $\mathrm{GH}$ in old mice, in conjunction with mild-exercise, efficiently inhibits Sarcopenic symptoms, including muscle atrophy and decreased protein synthesis. Of note, age-related decreases in cellular IGF-1 have been shown to adversely affect motor neuron function during aging (16). Transgenic mice were used to study the effects of sustained IGF-I overexpression during neuromuscular innervation, which showed that IGF-I prevents age-related alterations in nerve terminals and neuromuscular junctions (16).

Inflammation. Additionally, growing evidence suggests that age-related activation of inflammatory pathways is associated with elevated rates of muscle protein degradation, providing a mechanistic-link to Sarcopenia (17). Evidence suggests that the ubiquitin-proteasome pathway is instrumental for the induction of muscle-breakdown and is stimulated by inflammatory cytokines - tumor necrosis factor-alpha (TNF- $\alpha$ ) and interleukin-6 (IL-6) (18). One report (19) investigated the plasma cytokine profiles of 1411 participants (25-91 years in age) and found that IL-6 and TNF- $\alpha$ concentrations were 2 .4-fold and 2-fold higher in the elderly, respectively. This link between age-related increase in inflammatory markers and Sarcopenia is supported by a study that used computed tomography (CT) to asses the changes in thigh muscle area in 2177 participants during a span of 5 years, and found a consistent association between elevated serum-concentrations of IL- 6 and TNF- $\alpha$ and greater reductions in thigh muscle area (20). Furthermore, reinforcing this idea is an animal study (21), in which administration of an anti-inflammatory drug (ibuprofen) in old-mice significantly reduced muscle-mass loss during the span of 5-month treatment.

Age-Related Morphological Changes. Age-related muscle atrophy is associated with substantially decreased numbers and size of muscle fibers, and particularly, sizedecrease of type II (fast-twitch) muscle fibers by $10-40 \%$ (22), which likely contributes to declining muscle-strength with increased age. An autopsy study (23) concerning two age-groups (72 \pm 1 and $30 \pm 6$ mean ages) reported an $18 \%$ reduction in the muscle size of $m$. vastus lateralis and a $25 \%$ decrease in the number of muscle fibers in the older age-group. Additionally, accompanying type II muscle fiber atrophy is the aging-associated decrease of satellite cells contents and function (24). Satellite cells, otherwise known as muscle stem cells, are instrumental in muscle growth and regeneration; therefore, their age-rela- 
ted decline is being increasingly linked to Sarcopenia (25).

Another age-related morphological change that occurs in skeletal muscle is the increased muscle fat infiltration (myosteatosis) - the elevated deposition of lipids within muscle fibers or adipocytes (26). This study (26) found that throughout a 5-year span, $30 \%$ and $50 \%$ increases in intermuscular adipose tissue (mid-thigh area) were observed for women and men (70-79 years old), respectively. Fat-accumulation in skeletal muscle is now considered as an important contributing factor for the impaired physical-capabilities and reduced-mobility observed in the elderly (27).

\section{Conclusions}

1. A multitude of etiological factors influences the agingassociated deterioration of muscle mass and function that constitute Sarcopenia, such as imbalanced protein synthesis and degradation, decreasing anabolic hormones, inflammation, and age-related morphological changes, which are described in the review.

2. In the future, research might be conducted for identifying specific biomarkers, which may lead to an opportunity to assess and monitor the disease non-invasively, granting possibilities for a more efficient therapeutic approach.

\section{References}

1. Landi F, Calvani R, Cesari M, Tosato M, Martone AM, Ortolani E, et al. Sarcopenia: an overview on current definitions, diagnosis and treatment. Curr Protein Pept Sci 2018;19(7):633-638. https://doi.org/10.2174/1389203718666170607113459

2. Walston JD. Sarcopenia in older adults. Curr Opin Rheumatol 2012; 24(6):623-627.

https://doi.org/10.1097/BOR.0b013e328358d59b

3. Cruz-Jentoft AJ, Sayer AA. Sarcopenia. Lancet 2019; 393 (10191):2636-2646. https://doi.org/10.1016/S0140-6736(19)31138-9

4. Gielen E, O'Neill TW, Pye SR, Adams JE, Wu FC, Laurent MR, et al. Endocrine determinants of incident sarcopenia in middleaged and elderly European men. J Cachexia Sarcopenia Muscle 2015;6(3):242-52.

https://doi.org/10.1002/jcsm.12030

5. Yu R, Wong M, Leung J, Lee J, Auyeung TW, Woo J. Incidence, reversibility, risk factors and the protective effect of high body mass index against sarcopenia in community-dwelling older Chinese adults. Geriatr Gerontol Int 2014;1:15-28. https://doi.org/10.1111/ggi.12220

6. Dodds RM, Granic A, Davies K, Kirkwood TB, Jagger C, Sayer AA. Prevalence and incidence of sarcopenia in the very old: findings from the newcastle $85+$ study. J Cachexia Sarcopenia Muscle 2017;8(2):229-237.

https://doi.org/10.1002/jcsm.12157
7. Beaudart C, Zaaria M, Pasleau F, Reginster JY, Bruyère O. Health outcomes of sarcopenia: a systematic review and meta-analysis. PLoS One 2017;12(1):e0169548.

https://doi.org/10.1371/journal.pone.0169548

8. Norman K, Otten L. Financial impact of sarcopenia or low muscle mass - a short review. Clin Nutr 2019;38(4):1489-1495. https://doi.org/10.1016/j.clnu.2018.09.026

9. Koopman R, van Loon LJ. Aging, exercise, and muscle protein metabolism. J Appl Physiol 2009;106(6):2040-8. https://doi.org/10.1152/japplphysiol.91551.2008

10. Cuthbertson D, Smith K, Babraj J, Leese G, Waddell T, Atherton $\mathrm{P}$, et al. Anabolic signaling deficits underlie amino acid resistance of wasting, aging muscle. FASEB J 2005;19(3):422-4. https://doi.org/10.1096/fj.04-2640fje

11. Wall BT, Gorissen SH, Pennings B, Koopman R, Groen BB, Verdijk LB, et al. Aging is accompanied by a blunted muscle protein synthetic response to protein ingestion. PLoS One 2015;10(11):e0140903.

https://doi.org/10.1371/journal.pone.0140903

12. Sakuma K, Yamaguchi A. Sarcopenia and age-related endocrine function. Int J Endocrinol 2012; 2012:127362.

https://doi.org/10.1155/2012/127362

13. Lapauw B, Goemaere S, Zmierczak H, Van Pottelbergh I, Mahmoud A, Taes Y, et al. The decline of serum testosterone levels in community-dwelling men over 70 years of age: descriptive data and predictors of longitudinal changes. Eur J Endocrinol 2008;159(4):459-68.

https://doi.org/10.1530/EJE-07-0873

14. Veldhuis JD, Liem AY, South S, Weltman A, Weltman J, Clemmons DA, et al. Differential impact of age, sex steroid hormones, and obesity on basal versus pulsatile growth hormone secretion in men as assessed in an ultrasensitive chemiluminescence assay. J Clin Endocrinol Metab 1995;80(11):3209-22. https://doi.org/10.1210/jcem.80.11.7593428

15. Andersen NB, Andreassen TT, Orskov H, Oxlund H. Growth hormone and mild exercise in combination increases markedly muscle mass and tetanic tension in old rats. Eur J Endocrinol 2000;143(3):409-18. https://doi.org/10.1530/eje.0.1430409

16. Messi ML, Delbono O. Target-derived trophic effect on skeletal muscle innervation in senescent mice. J Neurosci 2003;23(4):1351-9. https://doi.org/10.1523/JNEUROSCI.23-04-01351.2003

17. Jo E, Lee SR, Park BS, Kim JS. Potential mechanisms underlying the role of chronic inflammation in age-related muscle wasting. Aging Clin Exp Res 2012;24(5):412-22.

18. Lang T, Streeper T, Cawthon P, Baldwin K, Taaffe DR, Harris TB. Sarcopenia: etiology, clinical consequences, intervention, and assessment. Osteoporos Int 2010;21(4):543-59. https://doi.org/10.1007/s00198-009-1059-y

19. Stowe RP, Peek MK, Cutchin MP, Goodwin JS. Plasma cytokine 
levels in a population-based study: relation to age and ethnicity. J Gerontol A Biol Sci Med Sci 2010;65(4):429-33.

https://doi.org/10.1093/gerona/glp198

20. Schaap LA1, Pluijm SM, Deeg DJ, Harris TB, Kritchevsky $\mathrm{SB}$, Newman AB, et al. Higher inflammatory marker levels in older persons: associations with 5-year change in muscle mass and muscle strength. J Gerontol A Biol Sci Med Sci 2009;64(11):1183-9.

https://doi.org/10.1093/gerona/glp097

21. Rieu I, Magne H, Savary-Auzeloux I, Averous J, Bos C, Peyron MA, et al. Reduction of low grade inflammation restores blunting of postprandial muscle anabolism and limits sarcopenia in old rats. J Physiol 2009 ;587( 22):5483-92.

https://doi.org/10.1113/jphysiol.2009.178319

22. Lexell J, Taylor CC, Sjöström M. What is the cause of the ageing atrophy? Total number, size and proportion of different fiber types studied in whole vastus lateralis muscle from 15 - to 83-year-old men. J Neurol Sci 1988;84(2-3):275-94.

23. Lexell J, Henriksson-Larsen K, Winblad B, Sjostrom M. Distribution of different fiber types in human skeletal muscles: effects of aging studied in whole muscle cross sections. Muscle Nerve 1983;6:588-595.

https://doi.org/10.1002/mus.880060809

24. Verdijk LB, Snijders T, Drost M, Delhaas T, Kadi F, van Loon LJ. Satellite cells in human skeletal muscle; from birth to old age. Age (Dordr) 2014;36(2):545-7.

https://doi.org/10.1007/s11357-013-9583-2

25. Renault V, Thornell LE, Eriksson PO, Butler-Browne G, Mouly $\mathrm{V}$. Regenerative potential of human skeletal muscle during aging. Aging Cell 2002;1(2):132-9.

https://doi.org/10.1046/j.1474-9728.2002.00017.x

26. Delmonico MJ, Harris TB, Visser M, Park SW, Conroy MB, Velasquez-Mieyer P. Longitudinal study of muscle strength, quality, and adipose tissue infiltration. Am J Clin Nutr 2009;90(6):1579-85.

https://doi.org/10.3945/ajen.2009.28047

27. Marcus RL, Brixner DI, Ghate S, Lastayo P. Fat modulates the relationship between sarcopenia and physical function in nonobese older adults. Curr Gerontol Geriatr Res 2012;2012:216185. https://doi.org/10.1155/2012/216185

28. Marzetti E, Calvani R, Cesari M, Buford TW, Lorenzi M, Behnke BJ, Leeuwenburgh C. Mitochondrial dysfunction and sarcopenia of aging: from signaling pathways to clinical trials. Int J Biochem Cell Biol 2013;45(10):2288-301.

https://doi.org/10.1016/j.biocel.2013.06.024
29. Manini TM, Hong SL, Clark BC. Aging and muscle: a neuron's perspective. Curr Opin Clin Nutr Metab Care 2013;16(1):21-6. https://doi.org/10.1097/MCO.0b013e32835b5880

30. Picca A, Fanelli F, Calvani R, Mulè G, Pesce V, Sisto A, et al. Gut dysbiosis and muscle aging: searching for novel targets against sarcopenia. Mediators Inflamm 2018;2018:7026198.

https://doi.org/10.1155/2018/7026198

\section{SENĖJIMO SARKOPENIJA}

\section{K. Stiklioraitis, S. Stiklioraitis, L. Sereikaitė, M. Jasinskaitė,} Ž. Krivickas, A. Aldujeli

Raktažodžiai: sarkopenija, senėjimas, raumenų silpnumas.

Santrauka

İvadas. Sarkopenija yra su amžiumi susijusi būklè, kuriai būdingas raumenų silpnumas, sutrikusios fizinès funkcijos ir raumenų audinių kokybės pablogèjimas. Susidomèjimo sarkopenija priežastis yra akivaizdus šios ligos ryšys su pacientų sergamumu, mirštamumu, ilgai trunkančiu hospitalizavimu ir gyvenimo kokybės pablogejjimu. Šios apžvalgos tikslas - pristatyti kai kuriuos su amžiumi susijusius biologinius pokyčius, galinčius sukelti sarkopeniją.

Medžiaga ir metodai. Literatūros apžvalga atlikta remiantis Medline (PubMed), Google Scholar, Science Direct ir CAIRN duomenimis. Tyrimas atliktas remiantis straipsniais anglų arba prancūzų kalbomis, paskelbtais iki 2019 m. gruodžio 31 d. Tyrimui buvo atrinkti medicinos mokslo straipsniai, kurių antraštèse rasti žodžiai: „sarkopenija“ ir „senejjimas“ arba „raumenų netekimas“.

Rezultatai. Literatūros apžvalga atskleidè pagrindinius su amžiumi susijusių biologinių pokyčių, galinčių sukelti sarkopeniją, veiksnius. Šiai nesisteminei peržiūrai buvo panaudota 19 tyrimų. Analizuotos literatūros apžvalgos $(\mathrm{N}=5)$ ir nekontroliuojami tyrimai $(\mathrm{N}=14)$. Metodikos kokybė ribojo rezultatų aiškinimą ir ekstrapoliaciją. Kitas apribojimas buvo tyrimai, apimantys bandymus su gyvūnais. Tolesni tyrimai yra būtini, norint nustatyti panašių tyrimų koreliaciją tarp bandymų su gyvūnais ir žmonėmis.

Išvados. Apžvalgoje aprašyta daugybė etiologinių veiksnių, sukeliančių su senejimu susijusių raumenų masès ir funkcijos pablogèjimą, kurie konstatuoja sarkopeniją, pavyzdžiui, nesubalansuota baltymų sintezė ir skaidymasis, mažejantys anaboliniai hormonai, uždegimas ir su amžiumi susiję morfologiniai pokyčiai. Ateityje gali būti atliekami tyrimai, siekiant nustatyti konkrečius biologinius žymenis, ịgalinančius ịvertinti ir stebèti ligą neinvaziškai, suteikiant galimybių efektyvesniam terapiniam gydymui.

Adresas susirašinèti: simas.stiklioraitis@gmail.com

Gauta 2020-12-17 